\title{
消費者の周遊選択行動と購買地の属性を考慮した購買地の動態モデル THE DYNAMICS OF RETAIL ZONE CONSIDERING CONSUMERS’ TRIP-CHAINING BEHAVIOR AND ATTRIBUTES OF RETAIL ZONE
}

\author{
櫻 井 雄 大*, 今井 公太郎**，本間 健太郎*** \\ Takehiro SAKURAI, Kotaro IMAI and Kentaro HONMA
}

\begin{abstract}
This paper intends to express and analyze the dynamics of retail zones on virtual space from a viewpoint of consumers' choice behavior. Related on this study, there is a series of the representative previous studies established by Wilson A. G. which mainly deal with simplified consumers' choice behavior and retail zone. To improve them, we improve model in the two points shown below;

1. It considers consumers' trip-chaining behavior in addition to single choice behavior.

2. It distinguishes the several attributes of retail zone.

To improve these models, we suggest the methods to create different choice set according to each consumer. In this study, we find the results which have not been discovered in previous studies by the above-mentioned model improvements.

First, small retail zone tends to survive compared to the previous models.

Second, each of the small retail zones belongs to the particular big retail zone and the consumers who choose two retail zones consume in small retail zones, therefore, small retail zones enable to survive.
\end{abstract}

\section{Keywords : Discrete choice model, trip-chaining behavior, Retail zone, Attributes 離散選択モデル，周遊選択行動，購買地，属性}

\section{1. はじめに}

本研究は, 消費者の購買行動に着目して, 仮想空間上で購買地の 動態を表現し, 分析するものである。購買地の動態や, より大きな 意味で都市の動態に関寸る既往研究には多くの蓄積がある.古くは, 古典的立地論の代表であるウェーバーの工業立地論, クリスタラー の中心地理論などがある。これらは，ある工場や教育施設の立地を 様々な諸条件から導くもので, 新規施設の到来による周辺への影響 を議論している。本研究に直接関連している既往研究として, Harris ら 1)やWilson ${ }^{2}$, 本間ら ${ }^{3)}$ の研究がある。これらは, 購買地 の動態を次の要領で分析している。消費者の購買額をエントロピー 最大化モデルなどの配分モデルに従って各購買地一配分し, その配 分された額をもって次なる購買地の規模（魅力度）を決定し，この 一連の流れを繰り返すものである。ここでは，購買地の規模と距離 のパラメータの組み合せにより購買地の分布が変化することを示し ている.

本研究では, 上記の既往研究に対して $2 つ の$ 拡張を試みる. 第一 の拡張は, 消費者が単一の購買地を選択する行動（以下，単一選択 行動）に加え, 周遊的に選択寸る行動（以下, 周遊選択行動）を導 入すること. 第二の拡張は, 購買地の属性（財の種類，業種）を考
慮することである。これらの拡張により，既往研究よりもさらに詳 細で現実に沿った動態現象を捉えることが可能になると考えられる。 第 2 章では, 既往研究における購買地の動態モデルの再現とその 性質の確認を行う。第 3 章では, 動態モデルの第一の拡張を行う. 消費者の周遊行動を考慮した選択行動モデルを構築し，そのモデル を導入して購買地の動態的な変化をシミュレートする.ここでは, 既往研究における動態モデルと比較し，周遊選択行動を考慮した場 合の差異を明らかにする，続く第 4 章では，動態モデルの第二の拡 張を行う. 第 3 章で構築する動態モデルに加えて, 購買地の属性を 考慮する．ここでも第 2,3 章と同じく購買地の動態的変化をシミ ユレートして分析する. 終章では, 本研究から得られた知見をまと め, 今後の課題を述べる.

\section{2. 購買地の動態モデル概要}

本章では，既往の動態モデルと同等なモデルを構築し，その再現 と性質の確認を行う。先ず，消費者の購買地に対する選択行動モデ ルを構築し, 次いで購買地の動態モデルを構築する.

\section{1 消費者の購買地選択行動モデル}

消費者の購買地に対する選択行動モデルに関する研究 ${ }^{4}$ は, 多く
* 東京大学大学院工学系研究科建築学専攻 博士課程 $\cdot$ 工修

** 東京大学生産技術研究所 教授.工博

*** 東京大学生産技術研究所 特任助教・工博
Graduate Student, The Univ. of Tokyo, M. Eng.

Prof., Inst. of Industrial Science, The Univ. of Tokyo, Dr. Eng.

Assistant Prof., Inst. of Industrial Science, The Univ. of Tokyo, Dr. Eng. 
の蓄積があるが, その中でも中心的なものとして, 離散選択モデル がある. このモデルは, 効用最大化理論に基づき, 個人は効用を最 大化するように行動するという仮定の下, 対象を選択する確率を導 出するものである. 本研究では, 離散選択モデルの中で, 最も簡潔 な式で表されるロジット型を用いる.

仮想空間上に分布する全ての購買地が含まれる集合を $A$ とする. 本章では, 全ての消費者は全ての購買地を選択肢として認識してい ると仮定する. 従って, 全ての消費者の選択肢集合は $A$ である. 消 費者 $n$ が選択肢集合 $A$ の要素である購買地 $i(i \in A)$ から受ける効用 $U_{n i}$ を観測者の観測できる確定的効用 $V_{n i}$ と, 観測者の観測できない不確 定的効用 $\varepsilon_{n i}$ の線形和で表現すると効用関数は,

$$
U_{n i}=V_{n i}+\varepsilon_{n i}
$$

となる. 不確定的効用 $\varepsilon_{n i}$ を確率変数であると考え, これが消費者と 購買地に関して独立で同一のガンベル分布に従うと仮定すると, 消 費者 $n$ の購買地 $i$ に対する選択確率が求まり, ロジット型の離散選択 モデルが導出される：

$$
P_{n i}=\frac{\exp V_{n i}}{\sum_{j \in A} \exp V_{n j}}
$$

既往研究では一般的に効用関数 $U_{n i}$ の確定的効用 $V_{n i}$ を,

$$
V_{n i}=\alpha \log s_{i}-\beta d_{n i}
$$

と定義している．ここに， $s_{i}$ は購買地 $i の$ 規模， $d_{n i}$ は消費者 $n$ が存在 寸る地点から購買地 $i$ までの距離， $\alpha, \beta$ は正のパラメータである. 購買地 $i$ の規模 $s_{i}$ を対数化しているが, これは消費者の受ける効用は 購買地の規模が対数関数的に作用すると考えられるためである. こ こで特筆すべきは, 式（3）を式（2）に代入すると拡張八フモデル と同等なモデル式になり, 式 (3) の右辺第 2 項の距離項を $\beta \log d_{n i}$ と すると発生制約型のエントロピー最大化モデルと同等なモデル式に なる注 1 ). 次に既往研究における確定的効用関数と同様なものを用 いて購買地の動態モデルを構築する.

\section{2 購買地の動態モデル（既往モデル）}

前節でモデル化した消費者の購買地選択行動モデルを用いて, 購 買地と消費者の需要供給の関係を記述し, 購買地の動態モデルを構 築する. ある空間に居住地と購買地が散在している状況を考える. ここで, 空間に境界があると境界付近の購買地が中心に位置する購 買地と比較して不利に働くため, トーラス状の空間を想定する.こ の空間に存在する地点 $r$ の集合を $R$ とし, 集合 $R$ の全ての地点に人口 $k_{r}(r \in R)$ が居住しているものとする. また, 購買地はこれらの地点 のどこかに分布し, 消費者は式 (2) の選択確率で購買地一出向す るものとする.ここで, 消費者から購買地までの距離はユークリッ ド距離とし, 消費者は地点に依らず同質であるとする. 従って, 全 ての消費者の選択肢集合は $A$ であり, 消費者 $r$ は地点 $r$ と同義である. 以下では, 地点 $r$ の消費者を消費者 $r$ と表現する.ここで, 総人口を $K$, 空間内に存在する購買地の総規模を $S$, 購買地 $i の$ 規模を $s_{i}$, 来訪者 数を $v_{i}$ とすると, 次の関係がある。

$$
\begin{gathered}
K=\sum_{r \in R} k_{r}=\sum_{i \in A} v_{i} \\
S=\sum_{i \in A} s_{i}, v_{i}=\sum_{r \in R} P_{r i} k_{r}
\end{gathered}
$$

ここで, 消費者と購買地の需要供給関係を,

$$
S D=\frac{S}{K}
$$

と定める.これは, 初期状態で与えられた人口と購買地の規模で決 定されるもので，一人当たりに供給する購買地の規模を表し，時間 によらず一定であるとする，従って，消費者と購買地の需要供給の 関係は一意に定まる值 $(S D=$ const. $)$ であり，この仮想空間での経 済的な状況は常に一定であるとする. 次に購買地が時点 $t$ で獲得した 来訪者からの受益により時点 $t+1$ での購買地の増床と減床を考え る. 時点 $t$ での購買地 $i の$ 規模を $s_{i}^{(t)}$, 購買地 $i$ に来訪した人数を $v_{i}^{(t)}$ と する. 時点 $t+1$ の購買地の規模は, 時点 $t$ で獲得した来訪者数と, 仮想空間全体の消費者と購買地の需要供給の関係に依拠していると 考えられる。購買地は時点 $t$ で獲得した来訪者数に対して式（6）の 関係を保つように供給すると考えると, 時点 $t+1$ での購買地 $i の$ 規模 $s_{i}^{(t+1)}$ は,

$$
s_{i}^{(t+1)}=S D v_{i}^{(t)}
$$

と表現できる．従って，このシミュレーションでは時を経るに従い 初期状態で一意に定められた需要と供給のバランスに近づくもので, 全ての購買地の規模が前時点と変化がないとき, すなわち購買地の 状態が,

$$
s_{i}^{(t+1)}=s_{i}^{(t)}, \forall i \in A
$$

を満たすとき，収束するものとする．

以上の購買地の動態モデルでシミュレーションを行う前に, 消費 者の選択行動モデルから読み取れるシミュレーションの挙動につい て整理する.

この動態モデルでは, 消費者の選択行動が結集した結果である来 訪者数により購買地の規模が変化するため, 式 (2) の消費者の選 択行動のモデル式が直接的にシミュレーションの挙動を左右する. このモデル式の分母は全ての消費者で共通しているため（全ての消 費者の選択肢集合が同じくAであるため), 挙動の把握はモデル式の 分子が特に重要である．選択確率のモデル式の分子を整理すると，

$$
\exp V_{n i}=S_{i}^{\alpha} \exp \left(-\beta d_{n i}\right)
$$

となる. 式（9）より規模効用につくパラメータ $\alpha$ （以下，規模パラ メータ） が $0<\alpha<1.0$ と $1.0 \leq \alpha$ の 2 つの場合で異なる挙動になる (図 2)．０< $\alpha<1.0$ であるときは，消費者が任意の 2 つの規模が異 なる購買地の規模から受ける効用（以下，規模効用）に差がなくな るため, 購買地までの距離から受ける効用（以下, 距離効用）が選 択行動の決定的な要因になる. 従って, 距離パラメータ $\beta$ が十分大 きければ，消費者は近傍の購買地を高い確率で選択寸るようになり 購買地の分布から作図されるボロノイ図の面積比で規模の大きさが 決定される.また, 距離パラメータ $\beta$ が十分小さければ，全ての購 買地をほぼ等確率で選択するため, 購買地の規模分布は初期状態の

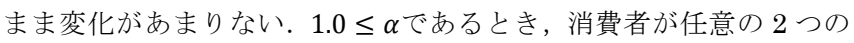
規模が異なる購買地から受ける規模効用に大きく差が開くため, 大 規模な購買地が有利な状況に, 小規模な購買地は距離パラメータ $\beta$ の大きさに関係なく不利な状況になる.

次に上記の動態モデルで具体的にシミュレーションを行う。 $100 \times 100$ 地点の仮想空間に人口 $k_{r}=100(r \in R)$ が分布し, 初期規模 500 の 10 の購買地がランダムに分布している状況を初期状態とす る. 図 1 に $\alpha=0.0, \beta=0.01$ の場合のシミュレーションの結果を示 す. 図の黒点は存続している購買地で, その点を覆う灰色の円の大 
きさは初期規模を, 括弧内の数字は購買地番号を示し, どの購買地 の勢力圏か一目で判明できるようにしている. 購買地の規模から受 ける効用が零である場合, 消費者の確定的効用は距離のみに依存す るため, 一次商圈注 2) は, ボロノイ図になる. 図 4 に $\beta=0.01$ に固 定注 3) して様々な $\alpha$ でシミュレーションを行った結果を示寸， $\alpha$ を大 きくしてゆくと規模の大きい購買地が独占的な状態になることが分 かる. $\beta=0.01 の$ 条件下では, $\alpha=1.55$ よりも大きければ, ただ一つ の購買地が存続し, 他の購買地は消滅する. 従って, 規模パラメー 夕аにより, 購買地の分布が離散的に分布するか一極に集中して分 布するか異なる結果になる. 尚, これらの実験結果は, 購買地の規 模や人口がランダムであっても規模分布は変わらない，以上は，消 費者の選択行動のモデル式などに若干の違いはあるが, 既往研究 1), 2),3)と同等なものである.

\section{3. 消費者の周遊行動を考慮した購買地の動態モデル}

本章では, 消費者の周遊行動を考慮した選択行動モデルを構築し, それを動態モデルに導入してシミュレーションを行う。周遊選択モ デルを扱う既往研究として本間 6)のものがある.これは, 複数の購 買地を周遊しながら選択する行動（以下，周遊選択行動）と一つの 購買地を選択寸る行動（以下，単一選択行動）を同列に扱い，ロジ ット型の離散選択モデルに導入するものである．周遊選択肢を考慮 すると, 消費者の選択肢集合が飛躍的に大きくなるが，本間の研究

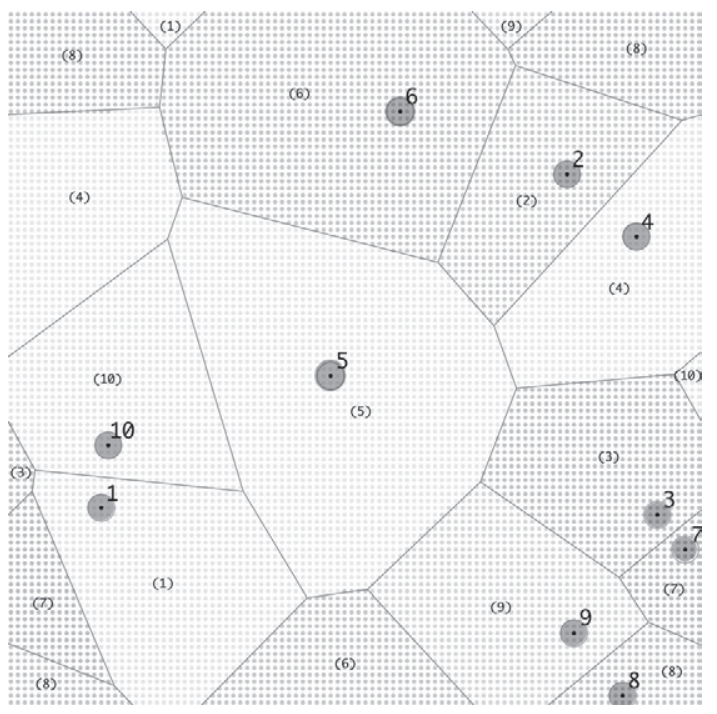

$\alpha=0.00 \quad \beta=0.01$

図 1 基礎モデルの収束結果

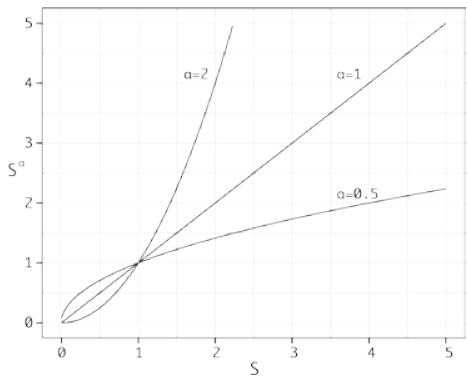

図 2 パラメータ $\alpha$ にる規模効用の差異
では選択肢集合に関する議論されていない，本章では，選択肢集合 の形成について簡潔な論理を導入して任意の地点に存在する消費者 にとって適切な選択肢集合を導く.

\section{1 周遊行動を考慮した消費者の購買地選択行動モデル}

周遊選択モデルを扱う本間の研究では，周遊行動で来訪する複数 の購買地をそれらの組み合せとして一つの選択肢として考えるもの である.このモデルに多少の改良を施す.

周遊選択行動を考慮した消費者の選択肢集合をBとする．全ての 消費者の選択肢集合は共通して $B$ であり, 2 つの購買地のみを周遊す るとき，選択行動モデルは式（2）の選択肢集合 $A$ を $B$ に置換し，周 遊選択肢 $\{i, j\}$ に対する確定的効用 $V_{r i j}$ を

$$
V_{r i j}=\alpha \log \left(s_{i}+s_{j}\right)-\beta\left(d_{r i}+d_{i j}+d_{j r}\right)
$$

としたものになる。ここに，周遊選択肢の場合，消費者は帰路を考 慮して選択行動をしていると考えられるため, 距離項を購買地から の帰路を考慮したものにしている，このモデルは，現実的に考えら れない購買地の組み合せ，例えば，消費者から遠い地点に存在する 2 つの小規模な購買地の組み合せなどが選択肢集合に含まれている。 この問題を解決するため，以下に記す周遊選択肢が選択肢集合に含 まれる条件を導入することで，適切な選択肢集合を導く，先ずは， 出発点として, 既往研究に倣い全ての消費者の選択肢集合には，全 ての単一選択肢と全ての可能な $2 つ の$ 購買地の組み合せからなる周 遊選択肢が含まれているものとする．また，1 つ目に来訪する購買 地はより近い距離に位置するものとする注4).

条件1：消費者がある周遊選択肢を選択寸る場合， 2 つ目に来訪 する購買地は，1 つ目に来訪する購買地よりも規模が大きく なければならない。

これは， 2 つ目に来訪する購買地が 1 つ目に来訪する購買地より も小規模ならば， 2 つ目の購買地で満足できる効用は 1 つ目に来訪 する購買地でも同じく満足でき, 来訪する必要がないと考えられる ためである。

条件2：消費者がある周遊選択肢を選択する場合，周遊選択肢の 方がその周遊選択肢内の購買地を単一選択寸る場合よりも確 定的効用が高くなければならない。

以下に具体的な状況を示しながら説明する（図 3). 地点 $r$ の消費 者が購買地 $i$ 之購買地 $j$ の組み合せを選択する状況を考える.ここで, $s_{i}>s_{j}$ とする. 条件 1 より, 大規模な方の購買地 $i の$ 単一選択肢と周 遊選択肢を比較する。これらの選択肢から受ける確定的効用は式 (3) と式（10）である。ここで，周遊選択肢 $\{i, j\} か ゙$ 選択肢集合に含まれ るためには， $V_{r i}<V_{r i j}$ が成立しなければならないから，

$$
\alpha \log \left(s_{i}+s_{j} / s_{i}\right)>\beta\left(d_{i j}+d_{j r}-d_{r i}\right)
$$

を満た寸場合においてのみ周遊選択肢 $\{i, j\}$ が選択肢集合に含まれる これは，周遊選択肢と単一選択肢から受ける規模効用の差分が，周 遊することで移動しなければならない単一選択行動との距離効用の

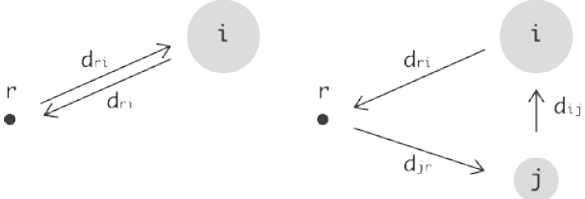

図 3 単一選択肢と周遊選択肢の比較 


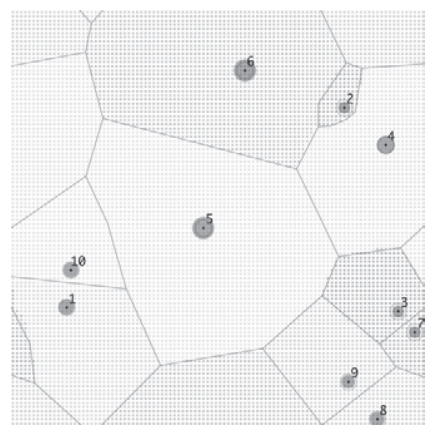

(a) $\alpha=0.90 \quad \beta=0.01$

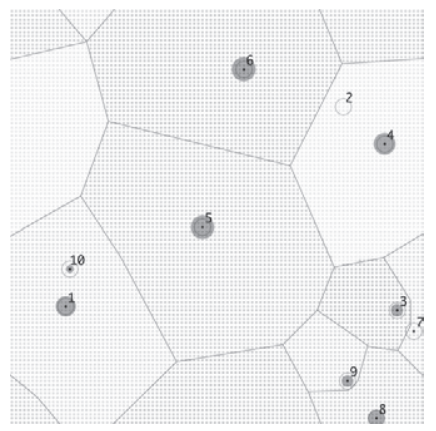

(b) $\alpha=1.00 \quad \beta=0.01$

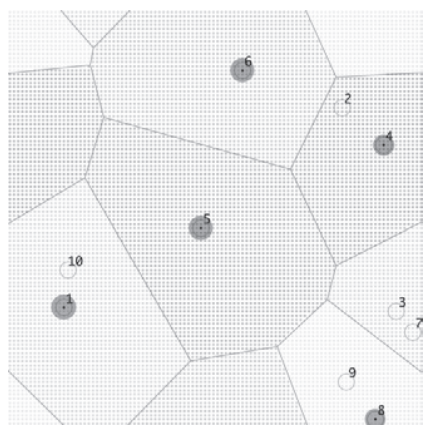

(c) $\alpha=1.10 \quad \beta=0.01$

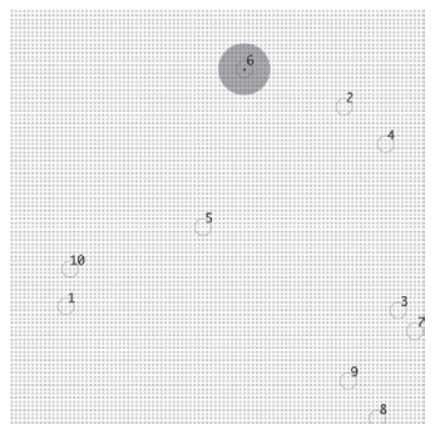

(d) $\alpha=1.55 \quad \beta=0.01$

図 4 単一選択モデルに基づく購買地の動態モデルの収束結果

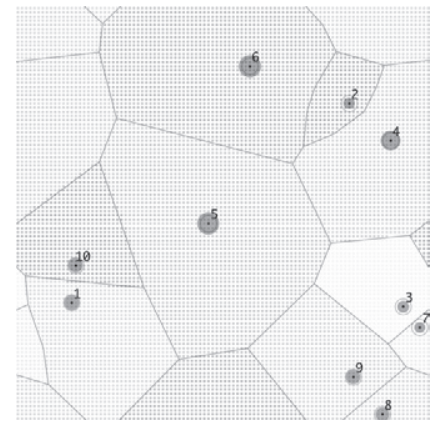

(a) $\alpha=0.90 \quad \beta=0.01$

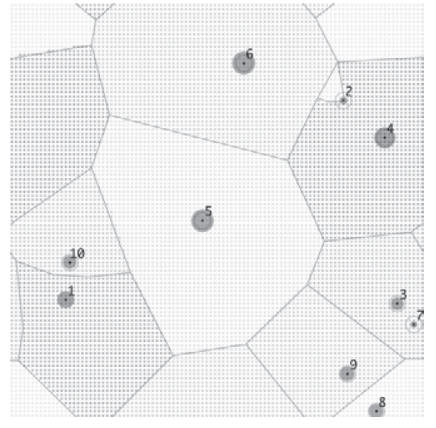

(b) $\alpha=1.00 \quad \beta=0.01$

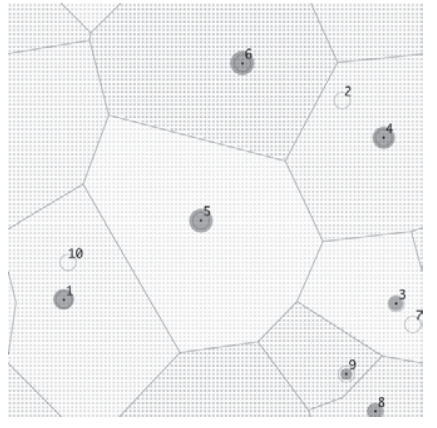

(c) $\alpha=1.10 \quad \beta=0.01$

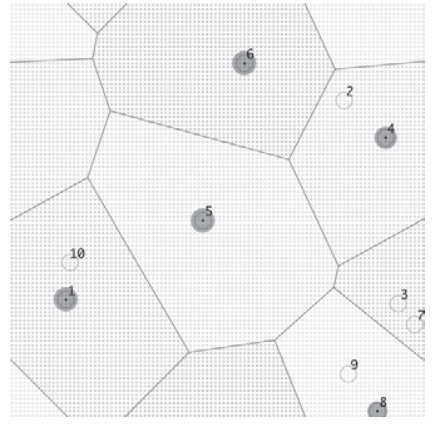

(d) $\quad \alpha=1.55 \quad \beta=0.01$

図 5 周遊選択モデルに基づく購買地の動態モデルの収束結果

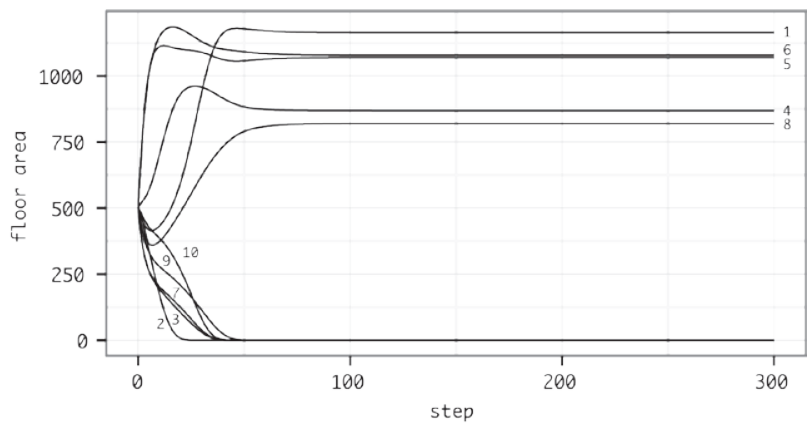

（a） 単一選択モデル（既往モデル）の場合（ $\alpha=1.10, \beta=0.01)$

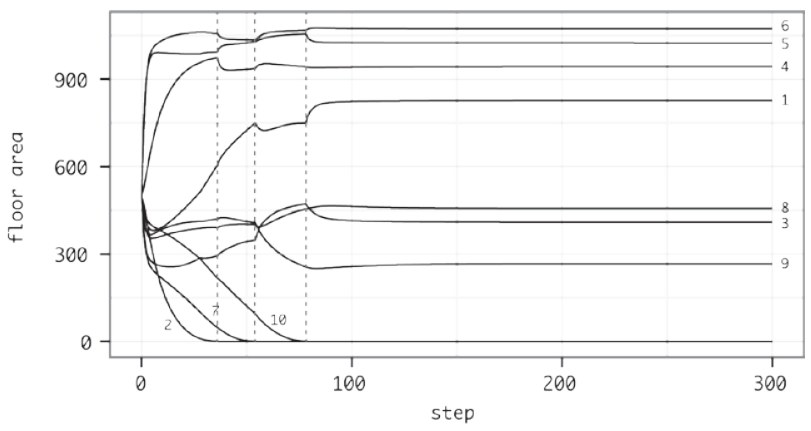

(b) 周遊選択モデルの場合 $(\alpha=1.10, \beta=0.01)$

図 6 購買地の規模推移

差分を比較したとき，規模効用が上回るときのみ周遊選択肢が選択 肢集合に含まれるとするものである.

以上の条件により消費者每に異なる選択肢集合が形成される．地 点 $r$ の消費者の選択肢集合を $D_{r}\left(D_{r} \subset B\right)$ とする. この選択肢集合 $D_{r}$ を ロジット型の離散選択モデルに組み込んだものを消費者の周遊選択 モデルとする.

\section{2 購買地の動態モデルとその挙動}

前節で構築した消費者の周遊選択モデルを用いて購買地の動態的 な挙動を分析するため, 前章の購買地の動態モデルを改良する. 改 良点は，消費者が周遊行動をする際の購買額の配分方法である.

周遊選択肢に対寸る購買額の配分について考える. 単一選択肢に 対しては前章と同じような方法で購買額を配分するが, 周遊選択肢 についてはその組み合せの購買地に対する配分も考えなければなら ない，消費者は大規模な購買地の方が小規模な購買地よりも多く消
費すると考え, その購買額が周遊選択肢内の購買地の面積比で配分 されるとする. 寸なわち, 周遊選択肢 $\{i, j\}$ の内, 購買地 $i に$ 割り振ら れる購買額 $v_{i}$ は,

$$
v_{i}=\sum_{r \in R} P_{r i} k_{r}+\sum_{r \in R} \sum_{\{i j\} \in \Lambda_{r}} P_{r\{i j\}} k_{r} \frac{s_{i}}{s_{i}+s_{j}}
$$

となる．ここに， $\Lambda_{r}$ は地点 $r$ の消費者の選択肢集合 $\mathrm{D}_{r}$ の内, 周遊選 択肢からなる集合である。

上記の動態モデルでシミュレーションを行った結果を図 5 に示す. 前章の基礎モデルと比較するため, 同じ条件で実験している. $0<\alpha<1.0$ である場合は, 単一選択モデルと周遊選択モデルともに 全ての購買地が存続しているが, 周遊選択モデルの方が小規模な購

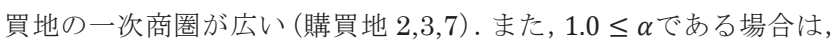
購買地が消滅している様子が伺えるが，同じパラメータでも周遊選 択モデルの方が消滅しにくい結果が出ている（図 4(b), 図 5(b)の購 
買地 2 など)。周遊選択モデルでは, 1 つの購買地が空間全体で独占 的な状態になる規模パラメータは $\alpha=2.65$ 付近で, 単一選択モデル の場合（ $\alpha=1.55 ）$ と比べて高い值である. 周遊選択肢に含まれる 2 つの購買地は，一方が成長すれば消費者の選択確率が高まるため, 次ステップではその恩恵を他方の購買地が受けることができる. 従 って, 小さな購買地は, 大規模な購買地が独占的な状態であるとし ても存続することが可能である.

次に規模推移の観点から単一選択モデルと周遊選択モデルを比較 する. 図 6 にそれぞれのモデルにおける規模推移を示す. 比較のた め，パラメータを両者共に $\alpha=1.10, \beta=0.01$ としている. 図 6 (a) は図 4 (c) に, 図 6（b) は図 5 (c) に対応している. 図 6 (b) よ り周遊選択モデルでは, 収束が比較的遅く, 激しい挙動を見せる. この非連続的な規模推移は, 購買地が消滅する際に消費者の選択肢 集合が変化しているためである. 例えば，最初に非連続的に規模が 変化する購買地 4,5,6 は, その時点で, 購買地 2 が消滅してしまう ため購買地 2 を含む周遊選択肢が全ての消費者の選択肢集合からな くなる. 従って, その時点までは周遊行動で得られていた購買額が なくなり, 一時的に衰退の様子を見せる. 周遊選択モデルでは, 一 つの購買地が消滅すると他の購買地に対する影響が強い. また, 単 一選択モデルと比べて立地的に不利な購買地（近傍に多数の競合す る購買地があるなど）でも存続し易い. 周遊行動による購買地の受 益は, 特に小規模な購買地において重要なものであることが分かる.

\section{4. 購買地の属性を考慮した購買地の動態モデル}

本章では, 前章における購買地の動態モデルに対し, 購買地の属 性を考慮することでさらなる拡張を試みる.ここで, 購買地の属性 とは，財種や業種のことである．

\section{1 購買地の属性を考慮した消費者の購買地選択行動モデル}

前章でも触れたように周遊行動における選択肢集合は消費者によ って異なる，本章では前章での選択肢集合を決定する論理に変更を 加えてまた別の論理を用意する，本研究では，簡単のためにいずれ の購買地も 2 つ属性を有寸るとする. 以下に属性を考慮した場合 の周遊選択肢が消費者の選択肢集合に含まれる条件を示寸．

条件：消費者がある周遊選択肢を選択する場合, 消費者が周遊 選択肢内の購買地を来訪寸る順序は，近傍からとし，2 つ目 に訪れる購買地は, その前に訪れた購買地よりも大きな規模 の属性（以下，属性規模）を 1 つ以上有していなければなら ない.

簡単な例を図 7 に示寸. 図 7 の括弧内は, 購買地の属性值を示し ている．消費者 $r$ から近い順序で購買地 $i, j, k, l$ がある状況を想定する. 周遊選択肢 $\{i, j\}$ は, 最初に訪孔る購買地 $i$ の方が全ての属性において 購買地 $j$ 以上であるため, 選択肢集合に含まれない。 また, 周遊選択 肢 $\{i, k\}$ は, 2 つ目に訪れる購買地 $k$ の属性 2 の規模が最初に訪れる購 買地 $i$ 属性 2 の規模よりも大きいため, 選択肢集合に含まれる.

以上の要領で消費者の選択肢集合を決定してゆくが，ここで特筆 すべきは, 属性を考慮した購買地に対する周遊行動では, 周遊する 経路が重要であるということである。本研究では, 周遊選択行動は 二つの購買地に対してしか行われないとしているため計算上は, 経 路は関係がない。 また, 周遊選択肢が選択肢集合に含まれるか否か は, 消費者の存在する地点により異なるため, 本章でも前章と同様
に消費者によって異なる選択肢集合が用意される.

次に属性を考慮した購買地に対する周遊選択モデルを定義する. 購買地 $i$ の属性を $i q$ と表現する。購買地 $i$ を選択する行動における確 定的効用関数を,

$$
V_{r i}=\sum_{q} \alpha_{q} \log s_{i q}-\beta d_{r i}
$$

と定義する。また，周遊選択肢 $\{i, j\}$ を選択する行動における確定的 効用関数を,

$$
V_{r i j}=\sum_{q} \alpha_{q} \log \left(s_{i q}+s_{j q}\right)-\beta\left(d_{r i}+d_{i j}+d_{j r}\right)
$$

と定義する。ここに， $s_{i q}$ は購買地 $i の$ 属性 $q$ の規模を表し， $\alpha_{q}, \beta$ は正 のパラメータである．式（13），(14）では属性による協調作用を表 現している主 5)。ここで，属性規模パラメータの含意について説明 する. $\alpha_{q}$ は対数化した規模の単位当たりの効用を示しているため, $\alpha_{1}>\alpha_{2}$ であれば属性 1 の方が一つの財で得られる効用が高いこと を示寸，従って， $\alpha_{1}=\alpha_{2}$ という関係が成り立つときは，属性 1,2 は 同一の財と解釈できるため本章でのシミュレーションでは， $\alpha_{q}$ を異 なる值で用意する.

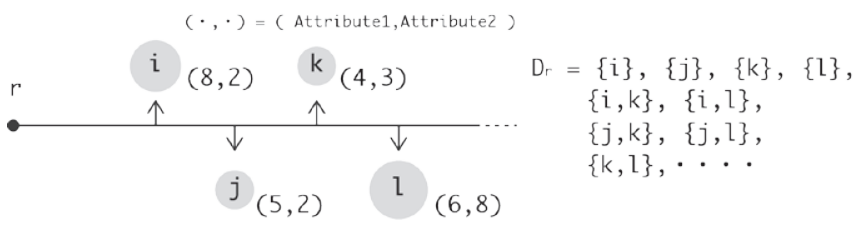

図 7 購買地の属性を考慮した消費者の選択肢集合の形成方法

\section{2 購買地の動態モデルのその挙動}

前節の選択肢集合の形成方法と確定的効用関数を導入した消費者 の選択行動モデルを用いて動態モデルを構築する. 先ず, 購買地の 属性を考慮するにあたり，式（6）のSD值を再定義する．消費者と 購買地の需要供給関係は, 購買地の属性毎で異なると考えられる. 従って, 属性毎の初期規模により

$$
S D_{q}=\frac{S_{q}}{K}, S_{q}=\sum_{i \in A} s_{i q}
$$

と定める. 次に一つの購買地の各属性に対する消費者の購買額の配 分を考える．購買地の属性を考慮したとき，消費者の購買額は属性 により配分が異なり, その配分には属性規模パラメータ $\alpha_{q}$ が関連し ていると考えられる. 従って, 周遊選択肢 $\{i, j\}$ の内, 購買地 $i$ の属性 $p$ に割り振られる購買額 $v_{i p}$ を,

$$
\begin{aligned}
v_{i p}=\sum_{r \in R} P_{r i} k_{r} \frac{\alpha_{p} \log s_{i p}}{\sum_{q} \alpha_{q} \log s_{i q}} \\
\quad+\sum_{r \in R} \sum_{\{i j\} \in \Lambda_{r}} P_{r\{i j\}} k_{r} \frac{\alpha_{p} \log s_{i p}}{\sum_{q} \alpha_{q}\left(\log s_{i q}+\log s_{j q}\right)}
\end{aligned}
$$

とする.

図 8,9 にシミュレーションの結果を示寸.図 8 は 10 の購買地で, 2 つの属性規模を共に 300 にし, 購買地の配置が 2 章, 3 章と同様 の初期条件で, 図 9 は 20 の購買地で属性規模をランダムに与えて いる. 括弧内はどの購買地の商圈かを表し，二つの番号がある場合 は周遊選択肢の商圈を表す。属性を考慮した周遊選択モデルでは, 周遊選択モデルよりも小さな規模の購買地が周遊選択肢として選択 

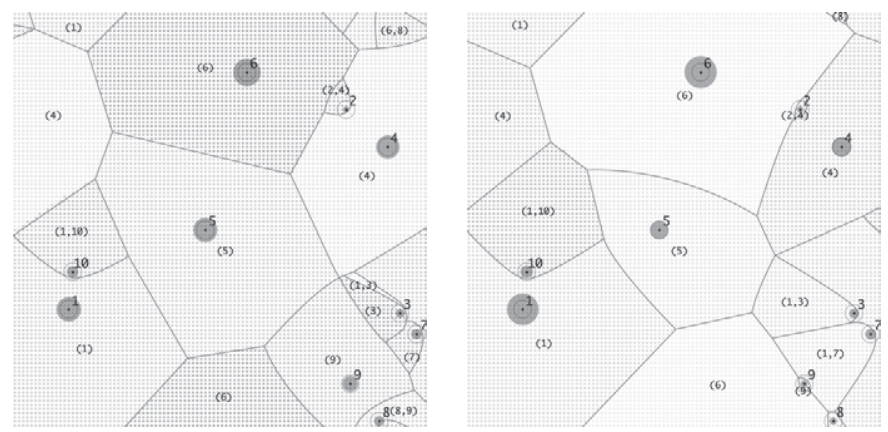

(a) $\alpha_{1}=0.80 \quad \alpha_{2}=0.70 \quad \beta=0.01$

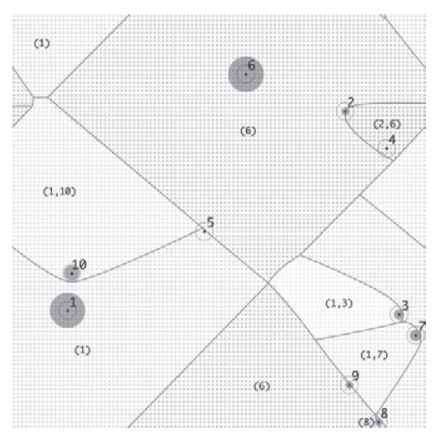

(c) $\alpha_{1}=1.00 \quad \alpha_{2}=0.90 \quad \beta=0.01$

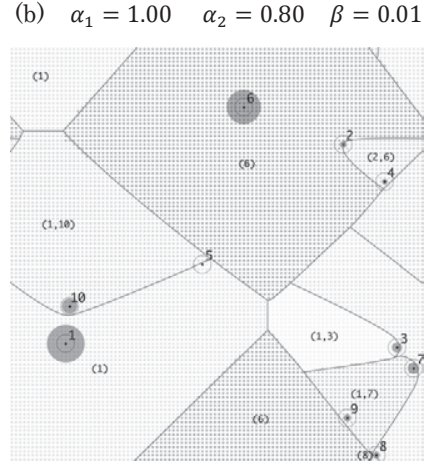

(d) $\alpha_{1}=1.20 \quad \alpha_{2}=1.10 \quad \beta=0.01$

図 8 周遊行動亡属性を考慮した購買地の規模分布

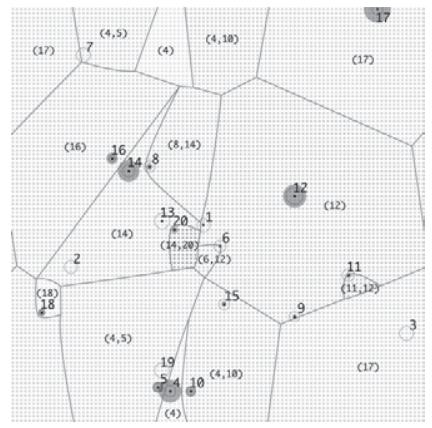

(a) $\alpha_{1}=1.00 \quad \alpha_{2}=0.90 \quad \beta=0.01$

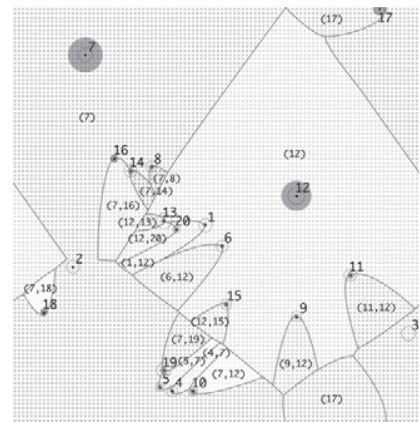

(b) $\alpha_{1}=1.10 \quad \alpha_{2}=0.90 \quad \beta=0.01$

図 9 周遊行動亡属性を考慮した購買地の規模分布

肢集合に含まれる可能性が高いため, 周遊選択モデルに比べて, さ らに購買地が存続し易い。また前章と同様に，小規模な購買地が他 の購買地の近傍に存在する (図 8 の購買地 1,10 や購買地 3,7 など) ならば消費者の周遊購買行動による受益が見込めるため存続し易い. 現実空間において, 居住地付近の小さな商店街の存続を説明する結 果がでている. 図 8 のシミュレーションの条件下では, $\alpha_{1}=1.0$, $\alpha_{2}=0.9$ 付近で規模分布が図 8(c)の商圈の形態に落ち着き, $\alpha_{1}, \alpha_{2}$ を 多少大きな值にしても多少の変化はあるものの大きな変化はない (図 8 (c), (d)). 図 9 でも同様に $\alpha_{1}=1.1, \alpha_{2}=0.9$ 付近で規模分布が 落ち着いた状態を見せる, 属性を考慮した周遊選択モデルでは, 図 8(c),(d)や図 9(b)のように購買地の帰属関係が明確に存在する. 小規 模な購買地は, 消費者の周遊行動により存続することが可能になる が，その周遊選択肢は帰属先の大きな購買地との組み合せである. 商圈図として 2,3 章と明らかに異なる点は, 購買地の帰属関係が 判然と寸る様であり, 周遊選択肢の商圈が出現するところである.

\section{5. 結語}

本研究では，購買地の動態を仮想空間上で表現し，消費者の選択 行動との関係を分析している。ここでは, 既往研究で提出されてい る購買地の動態モデルから 2 つの拡張を行っている. 第一に消費者 の周遊選択行動を導入していること, 第二に購買地の属性を導入し ていることである．消費者の周遊選択行動モデルを構築するにあた り，選択肢集合の形成論理を提案し，これにより消費者毎に異なる

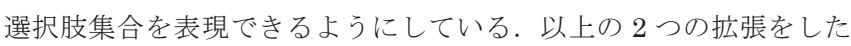
購買地の動態モデルを用いてシミュレーションを行ったところ，既 往モデルと明らかに異なる結果を得ている。第一に小規模な購買地 は消費者の周遊行動により存続し易いということ，第二に小規模な 購買地は, 大規模な購買地に帰属寸る関係にあるということである.

今後の展望としては，より複雑な状況を想定することである．例 えば，人口が変化する，外生的に購買地が新規参入する，空間の地 価を考慮するなどが挙げられる，また，実空間データを用いて，将 来の購買地の規模分布を予測することも挙げられる.

\section{参考文献}

1) Harris, B. , Wilson, A. G. : Equilibrium values and dynamics of attractiveness terms in production-constrained special interaction models, Environment and planning A, 10, pp.371-388, 1978

2) Wilson, A. : Boltzmann, Lotka and Volterra and spatial structural evolution: an integrated methodology for some dynamical systems, Journal of The Royal Society Interface, Vol. 5, no. 25, pp. 865-871, 2008 3）本間裕大・栗田治：顧客の店舗選択行動を考慮した商業発展のダイナミク ス-都市の形状と交通基軸パターンがバランスメカニズムに与える影響-, 都市計画論文集，Vol.40，pp.97-102，2005

4) Train, K. : Discrete choice methods with simulation, $2^{\text {nd }}$ Edition, Cambridge University Press, 2009

5）大山崇・鈴木勉：周遊Voronoi 図とそれを用いた商業立地分析，日本応用 数理学会論文誌, Vol.11, No. 1, pp. 1-14, 2001

6) 本間裕大：周回行動を考慮した競争的施設の最適立地問題一周遊がもたら 寸集積効果の分析-, 都市計画論文集, Vol.44, pp. 763-768, 2009

7) 栗田治: 輸送機間の発達が地域の商業売上に与える影響一ハフ・モデルに 基づく解析学的アプローチ-, 都市計画論文集, Vol. 44, pp. 55-60, 2002

注

注 1) 拡張八フモデルは, $P_{n i}=S_{i} \exp \left(-\beta d_{n i}\right) / \sum_{j \in A} S_{j} \exp \left(-\beta d_{n j}\right)$ と表現され, ロジット型の離散選択モデルと類似している。発生制約型のエントロピー 最大化モデルは, $P_{n i}=S_{i} d_{n i}{ }^{-\beta} / \sum_{j \in A} S_{j} d_{n j}{ }^{-\beta}$ で表現される.これは, ロジッ 卜型の離散選択モデルの確定的効用関数の距離項を, $-\beta \log d_{n i}$ とすると導 かれる7).

注 2) 購買地 $i$ の一次商圈とは, 購買地 $i$ 最も高い確率で選択する消費者が存 在する地点の集合とする.

注 3）本研究で想定している空間は，一辺が 792.0 の正方形をトーラスにし た空間であるため，最長距離は 560.0 である. $\beta=0.01$ のとき，選択確率 が半減する距離 (半減距離) は, 69.3 である. 本研究では, 都市に分布し ている商業集積地や商店街を念頭においているが，特に都市の大きさが最 長距離 560.0 に対して半減距離が 69.3 である都市を想定している.

注 4）この仮定は条件 1 に深く関連するものである.これは，周遊選択にお いて，より近い購買地がもう一方の購買地よりも大規模である場合，その 周遊選択肢は選択肢に含まれないとするのが自然であるという根拠からく る.

注 5）式（13）の規模項を整理すると, $\log \left(s_{i 1}\right)^{\alpha_{1}}\left(s_{i 2}\right)^{\alpha_{2}}$ である. 3 章の確定的 効用関数の規模項は, $\log \left(s_{i} / 2+s_{i} / 2\right)^{\alpha}$ と表現できる. 従って, 式 (13) で は，購買地の規模効用を属性規模の乗算で表現しているため, 協調関係を 表していると解釈できる. 